\title{
A Grounded Theory Approach to Reconstruct Brand Value Based on Prosumption Logic in the Era of Sharing Economy Platform
}

\author{
Lei Shen, Ye Chen ${ }^{\circledR}$, Chu Luo* \\ Glorious Sun School of Business and Management, Donghua University, Shanghai, China \\ Email: *rheachen0328@gmail.com
}

How to cite this paper: Shen, L., Chen, Y. and Luo, C. (2019) A Grounded Theory Approach to Reconstruct Brand Value Based on Prosumption Logic in the Era of Sharing Economy Platform. Theoretical Economics Letters, 9, 2975-2996. https://doi.org/10.4236/tel.2019.98184

Received: November 2, 2019

Accepted: December 14, 2019

Published: December 17, 2019

Copyright () 2019 by author(s) and Scientific Research Publishing Inc. This work is licensed under the Creative Commons Attribution International License (CC BY 4.0).

http://creativecommons.org/licenses/by/4.0/ (c) (i) Open Access

\begin{abstract}
The purpose of the article is to explore brand value in the era of sharing economy platform based on prosumption logic. This study used Charmaz's Constructivist Grounded Theory to analyze prosumers' reviews randomly collected 23 sharing economy platform brands from Baidu Reputation. After initial coding analysis, focus coding analysis and theoretical coding analysis, the brand value dimension structure model and the brand value dimension path model were constructed. We found that web 2.0 platform brand should pay full attention to the dominant role played by the prosumers, because the prosumers also play an important role in the brand as well as its value co-creation mechanism. And the brand should fully recognize the importance of competitors so as to enhance the brand value. It could dramatically raise the brand value by encouraging band evangelism and brand citizenship behavior. Additionally, this study is the first to come up with a new construct of brand value under the prosumption logic with its own five dimensions. All constructs and the categories are based on the existing concepts. The new core concepts and categories are prosumption experience, competitor association, prosumer image, prosumption outcome quality, perceived justice, competitive price, cumulative satisfaction, prosumer trust, brand future prediction, brand and prosumer attachment, business partner, using intention after being recommended, brand worship, prosumer worship, attacking competing brand, altruistic behavior, brand support and development behavior.
\end{abstract}

\section{Keywords}

Brand Value, Sharing Economy Platform, Prosumption Logic, Grounded Theory

\section{Introduction}

The primitive economy included highly integrated production and consumption 
(hereinafter referred to as prosumption), and it played a dominant role in the pre-industrial age. However, driven by market economy, society experienced a wedge-shaped evolution in which production was gradually separated from consumption: for two centuries since the first industrial revolution, the western economy had been defined by production; for nearly half a century, capitalist nations have stepped out of the primitive stage of industrialization as economy was increasingly defined by consumption. Since the $21^{\text {st }}$ century, information technology represented by Web 2.0 and social network has triggered a social change. Then at the end of 2007, a global economic crisis caused a decline in both consumption and production, lifting the curtain on a third wave of integrating production and consumption as well as rejecting the abnormal distinction between production and consumption [1]. In 2006, Toffler [2] made a prediction about the "pending spurt in the number of prosumers" and the threat that a society of consumption (and production) will face in the wake of the prosumer's society". Quain [3] published the book Pro-Sumer Power, introducing the concept of "prosumer era", and had been gradually gaining support from scholars. Inspired by this, Ritzer [4] wrote The Coming of Age of Prosumer to discuss the coming prosumer era. Whereas once the prosumption study was not familiar and mature to people, today it increasingly serves as a business strategy in business studies in the era of sharing economy platform [5].

The integration of production and consumption is the nature of the sharing economy [6]. With the advent of Web 2.0, the sharing economy-based on the prosumer's activity-is now reshaping how the economy is operated and has changed people's lifestyles with a resource evolution that brings about a brand-new approach to organize our economic lives. In such economic lives, individual users, with nearly zero marginal cost, are increasingly involved in the production, consumption and sharing of their commodities and services by joint efforts [7]. Therefore, studies seek insights into sharing economy platforms [8] [9].

In brand research, brand value theory is considered as one of the most influential theories in the marketing circle. Previous studies argued that brand value is mostly evaluated by consumers or enterprises and that-according to different evaluation subjects-brand value can be classified into three categories: the brand value based on consumers, the brand value based on the market and the brand value based on finance. Asker and Keller and other scholars believe that brand value is up to the consumer to decide, and most studies on marketing focus on the brand value based on consumers [10]. With the development of digital technology, the rise of prosumer capitalism represented by the sharing economy will fundamentally revolutionize the existing marketing theories, making the prosumer, not the consumer, the new evaluation subject of brand value. As a result, the brand value theory focusing on the consumer will give way to the one based on prosumption logic.

The formation of platform brand value is a process of value co-creation [11] [12]. In the process of co-creation in the era of web 2.0, consumers are no longer 
passive receivers of market information, they have mastered the initiative in creating content and participating in dialogue marketing [13]. Customers can change from passive audiences to active partners interacting with suppliers, so as to create brand value [11] [12] [14] [15]. Therefore, the process of brand value creation in the era of sharing economy platform has the characteristics of the formation mechanism of traditional brand value, and also the characteristics of platform which determine its new characteristics different from traditional brand building. The essence of prosumer participation in brand value co-creation lies in the combination of production and consumption. Through this richer understanding of prosumption, we gain insight into which dimensions constitute the brand value under the prosumption logic.

\section{Theoretical Foundations of Prosumption, Sharing Economy and Brand Value}

\subsection{Prosumption Logic}

In the past, the second wave of the market economy drove the wedge-shaped evolution of society, separating both production and consumption, and thereby giving birth to the goods-dominant logic that redefines the relationship between a consumer and producer as mere exchange of values [16]. The goods-dominant logic is a guiding framework that manages the production and the distribution of products (services). It is based on the premise of the separation between production and consumption and is centered on the value exchange between producer and consumer.

Every product delivered to the hands of consumers has to go through a series of steps from purchasing to sale, the process known as the Porter's value chain [17]. Most scholars concern themselves with what the consumer bought but not what the consumer did. The consumer was considered as a passive receiver, not as a creative individual. Therefore, consumption was forcedly separated from production [18]. Marx [19] argued that the difference between a consumer and producer lies in the difference between the exchange value and the use value, and that the producer produces products for the exchange value, whereas the consumer purchases a product for its use value. He held the perspective that the relationship between the producer and consumer is characterized by unity of opposites. For nearly two decades, scholars have argued against the dichotomy between production and consumption, and considered the two as a unity that cannot be separated.

Pietrykowski [20] considered the fact that production and consumption are separated as highly inappropriate, and argued that a consumer finds his ego and identity through every purchase behavior and also serves as part of the production process by making purchases, as well as that consumption is production in another form, thereby being an integrated part of production. There were also some scholars who tried to prove the unity between production and consumption, and they argued that in terms of its social role, the boundary between pro- 
ducer and consumer is becoming ever blurrier [21]. Toffler [22] used the term "prosumption" to describe a state where consumer engages more and more in use value rather than exchange value. prosumption is a continuous process in which people contribute their ideas to the product by adapting, modifying and changing the product. In a sense, prosumption is a process that makes no distinction between production and consumption.

In consistency with the concept of prosumption, Toffler [22] introduced the notion of "Prosumer" and predicated the "Rise of Prosumer". Later Kotler [23] came up with the term "Prosumer's Campaign". Toffler [2] argued that prosumers are the kind of people who create products, services or experiences for their own use or self-satisfaction but not for the purpose of selling or exchanging. Besides their love for prosumption activities, the major drive for the emergence of prosumption is the benefits from prosumption activities. Tapscott and Williams [24] regarded the prosumer as a part of the new "Wikinomics" model that consumers work for enterprises. They also debated on the difference between prosumption and the consumer-centric theory. According to them, prosumption regarded the consumer as part of the production process whereas consumer-centric theory means that enterprises provide basic options for consumers to further improve. Enterprises are disinclined to pay for the prosumers' production efforts and prosumers pay no or little money to cover the cost of their purchases.

Xie [18] and other scholars argued that prosumption is a process where value is created by both individual and seller, and that the consumption experience runs through the whole production process that produces products or services for the consumer. It is argued that prosumption is not just the combination of production and consumption, because the prosumer's experience does not just include the producer and consumer, but also involves their participation and innovation [25]. Studies on prosumer in China are still in the initial stage. Shen Lei and other scholars commented on the existing studies on the prosumer [26], probing into a prosumer's behaviors and types [27] [28] based on the e-business background, and carrying out empirical studies on prosumer value and its influence on brand value [29]. This paper holds that prosumers engage in both production and consumption, and co-create values with enterprises according to their own interests and expertise.

In recent years, the rapid development of web 2.0 and network technology has triggered a social change. The popularity of the Internet facilitates many studies and theories regarding prosumption logic, such as value co-creation and service-dominant logic.

While the goods-dominant logic becomes the mainstream theory, some scholars criticize the fact that a consumer is regarded as a passive receiver of value, and have then proposed theories like process orientation and value co-creation, etc. When it comes to economic evolution, Vargo and Lusch introduced the service-dominant logic, and at the same time they argued that "all forms of economy are service-oriented and value is born out of service offering" and that all 
products are actually services in various forms [12]. According to them, when purchasing a certain product, the consumer is after the services that the product provides, and the delivery of such services requires the consumer's knowledge on how to use and maintain the product, so that the product can meet the consumer's specific needs. The service-dominant logic refers to service as a process in which people do things for the benefit of others, not an accessory to a product. It is the product that is the medium by which consumers acquire services during the process of value creation. Service is the basic of all commercial transactions. An enterprise regards consumers as partners in value creation and focuses particularly on the process orientation rather than the output orientation of the service. It is vital to point out that the prosumption logic is different from the service-dominant logic even though it is a marketing philosophy built on the theories of value co-creation and service-dominant logic.

This paper summarizes the distinctions and relations among the three logics that are illustrated in Table 1.

Goods-dominant logic overlooks the consumers' voice. As a result, enterprises treat consumers as the marketing target, and the dialogue between them is defined as a one-way communication from the enterprise to the consumer with the former being an active producer of value and the latter being a passive value receiver. This relationship is called "market to consumer". Service-dominant logic regards consumers as a partner in the marketing value chain, and the relationship between enterprises and consumers is a nonlinear one in which the two can establish or cancel a dialogue at any time. Therefore, the enterprise conducts its marketing campaigns with the help of consumers (market with consumers) [30]. According to the prosumption logic, the prosumer is an active independent value creator, and the enterprise can help prosumers while being unable to make prosumers depend on the enterprise during value creation. Use value and exchange value can be created by the prosumer without the involvement of the enterprise, or the prosumer can work with the enterprise to create exchange value. The enterprise can also act in its best interests and exploit surplus value from the prosumer. This paper holds that the service-dominant logic is a transitional stage between the goods-dominant logic and the prosumption logic.

This paper agrees with Ritzer's view [1] of defining prosumption as a continuous process that makes no distinction between production and consumption, and regards them as two parts of a unity complementing each other instead of focusing solely on either of them; the term "Prosumer" is composed of the word "Producer" and the word "Consumer", which indicates that producer and consumer are one and the same. In summary, this paper believes that the prosumption logic is a guiding framework for managing value creation, based on the integration of production and consumption and centered on the fact that the prosumer creates value.

Since 2007, the American Marketing Association (AMA) has settled on the definition of marketing that paints a promising picture where everyone can conduct marketing. Such definition introduced the process orientation regarding 
Table 1. A comparison of value creation under different logics.

\begin{tabular}{llll}
\hline \multicolumn{1}{c}{ Goods-Dominant Logic } & \multicolumn{1}{c}{ Service-Dominant Logic } & \multicolumn{1}{c}{ prosumption logic } \\
Value creator & Enterprise & Enterprise and consumer & $\begin{array}{l}\text { Prosumer } \\
\text { Prosumer and enterprise } \\
\text { Form of value creation }\end{array}$ \\
Enterprise creates value & $\begin{array}{l}\text { Enterprise and consumer } \\
\text { co-create value }\end{array}$ & $\begin{array}{l}\text { Prosumer creates value alone } \\
\text { Prosumer creates value under the } \\
\text { supporting of the enterprise }\end{array}$ \\
End product & Consumer receives use value & $\begin{array}{l}\text { Enterprise helps consumer } \\
\text { produce use value }\end{array}$ & $\begin{array}{l}\text { Prosumer creates use value and } \\
\text { exchange value }\end{array}$ \\
Value producer & $\begin{array}{l}\text { Enterprise is the value producer } \\
\text { and consumer is the value receiver }\end{array}$ & $\begin{array}{l}\text { Enterprise is value co-producer } \\
\text { Consumer is value co-producer }\end{array}$ & $\begin{array}{l}\text { Enterprise, platform stakeholders, and } \\
\text { Prosumer }\end{array}$ \\
The process of value creation & $\begin{array}{l}\text { The production activity of } \\
\text { Enterprise }\end{array}$ & $\begin{array}{l}\text { The consumption activity of } \\
\text { consumer }\end{array}$ & $\begin{array}{l}\text { Prosumer produces and consumes } \\
\text { Exploiting potential product value to } \\
\text { achieve brand companies, distributors } \\
\text { and consumers a win-win strategy; re- } \\
\text { ceiving commissions for each transaction; } \\
\text { mixed mode }\end{array}$ \\
\hline
\end{tabular}

value creation and rejected the theory that value is only created by enterprises and institutions. It supports the argument on prosumption logic that consumer is no longer a passive value receiver, and places enough emphasis on activities featuring co-creation of value. It opens up a window for us to recognize other marketing philosophies along with goods-dominant logic, and also ushers in a new chapter of marketing philosophy where goods-dominant logic coexists with prosumption logic.

\subsection{Sharing Economy}

The sharing economy with the prosumer as the major player in the market's activities has fundamentally revolutionized the traditional industry, reshaping the way the global economy operates and is catching the attention from the industry and the academic society. Why does Airbnb, but not the traditional bed and breakfast, represent the sharing economy? Why is it that the website ZBJ.com, not the traditional labor market, fits into that definition? The sharing economy is also called "cooperative economy", "collaborative consumption" or "P2P economy". Botsman and Roger [31] mentioned that "in recent years, several new enterprises such as Airbnb have emerged. These enterprises share one thing in common - people provide and share underused resources through innovative new approaches, characterized by sharing economy or collaborative consumption". Botsman [32] argued that the sharing economy is an economic model where people share space, expertise or any other underused resources to acquire either financial or non-financial benefits, and classified the sharing economy into four categories: shared production, shared consumption, shared finance and shared knowledge (education). A good example of shared production is Quirky, which designs, produces and distributes products by working with the Internet; shared consumption means maximizing asset effectiveness through highly effi- 
cient redistribution and sharing, for example: Airbnb; shared finance refers to $\mathrm{P} 2 \mathrm{P}$ banking business and cloud-driven investment model designed to distribute financial investments, for example: Zopa; shared knowledge refers to P2P learning model featuring open education and universal education, for example: Coursera.

Different from the bilateral relationship between producer and consumer that features the traditional economic model, the core of the sharing economy lies in the integration of production and consumption, which makes it a different economic model from the traditional ones in five criteria [33]: different from the currency-dominant commodity transaction, the act of sharing blurs the social boundaries, producing and reproducing new social connections; different from the sharing among acquaintances like relatives and neighbors, the act of sharing among online strangers is the major feature of modern sharing economy; credit system built on crowd sourcing backdrop lowers the costs of sharing economy; traditional business transaction involves the permanent transfer of ownership and right to use, whereas sharing economy includes impermanent transfer of right to use; within the sharing economy, players are willing but not forced to share for the sake of personal survival; in addition, most sharing economies profit from taking commissions from every transaction whereas the traditional profit model is about maximizing the profits from every transaction.

\subsection{Brand Value}

Brand value is the most valuable intangible asset of an enterprise. In the past, the main point of view on brand value could be categorized into three types. The first one is from the financial point of view. It concerns with the cost of buying or selling of a brand as an intangible asset or the brand's value on the balance sheet, namely, the brand's financial performance. The second one is from the consumer's point of view. It reflects the psychological association and perception of the consumer in a purchasing behavior. The third one is from the angle of product market and mainly refers to the brand's market performance. Previous studies agreed that brand value is decided by consumer and brings corporate shareholders value. Christodoulides and Chernatony [10] argued that the brand value based on corporate finance indicates the consumer's response to the brand, while the brand value based on consumer was regarded as the driving force behind market shares and brand profitability. Therefore, most studies on marketing are focused on the structure, dimensions and the influence of the brand value based on consumer.

Previous studies often use Aaker or Keller's doctrine to understand brand values from a cognitive perspective and thus came up with many measurement scales. For example, many scholars follow the brand value assessment scales created by Yoo and Donthu [34] (brand awareness, brand loyalty, perceived quality, brand association and overall brand equity). However, Yoo and Donthu's ratings emphasize purchase intention, especially when it comes to measuring the overall brand equity. Recently, scholars have begun to attach importance 
to the emotional connections between the brand and the testees, and these connections are included in the brand value dimension. In addition to the theory of cognition, scholars began to evaluate the brand value from the perspectives of relation theory and empirical theory, increasing the quantity to the existing brand value evaluation dimensions. Moreover, although current studies on brand value do not engage directly in the development of brand value measurement models, they still zoom in on the testees and the corresponding brand-related perceptions and internal psychological reactions. The study construct employs brand value measurement dimensions in order to enhance the brand value. The corresponding documents further enrich the contents of the brand value measurement model. Brakus [35] and others argued that the brand experience is the sensory, emotional, cognitive and behavioral responses from consumers when they are inspired by brand-related elements (such as brand design, logo, packaging, etc.), and then introduced the brand value measurement scale from the angle of the theory of experience.

At the end of 2007, after the global recession, the demand for frugal consumption rocketed. The act of sharing, a rather ancient phenomenon, was therefore warmly welcomed once again on a large scale and accompanied by the development of digital technology innovation as well as the popularization of environmental awareness. Along with the take-off of the sharing economy comes the outbreak of the prosumer. The prosumers will replace consumers and producers and become the new major production subject, and the brand value based on the consumer will give way to the brand value based on the prosumer. The previous studies on brand value are based on the goods-dominant logic. Nevertheless, with the rise of web 2.0, the prosumption capitalism represented by sharing economy will fundamentally revolutionize the traditional marketing theories. Does the brand value model based on goods-dominant logic apply to the prosumption logic? What is the brand value model based on the prosumption $\operatorname{logic}$ ?

Although the definition of brand value varies among scholars, there is still a common ground among all the differences [36]. With the development of information technology as well as the integration of production and consumption, the consumer will be replaced by the prosumer under the prosumption logic. So, what is the structural dimension of the brand value based on the prosumption logic in the era of sharing economy platform?

\section{Research Design}

\subsection{Research Method}

Grounded theory is widely accepted as the most scientific qualitative research method and the ideal exploratory method for theory generation. Previous studies failed to analyze the brand value based on the prosumption logic. To solve related problems, a new theory must be constructed. Therefore, after nearly 50 years of development, the grounded theory gave form to three schools that are both interrelated and critical of one another: classical grounded theory, proce- 
dural grounded theory and constructivist grounded theory. This paper used the research paradigm of Charmaz constructivist grounded theory and Suddaby's [37] principle as reference to explore the brand value under the prosumption logic. The research process [38] is demonstrated in Figure 1.

\subsection{Data Collection and Theoretical Sampling}

This study refers to Lassar and some other scholars' [39] premises of brand value and holds that the brand value refers to the subjective view of the evaluator. When exploring the brand value based on the prosumption logic, this study collects prosumers' subjective views on brands as original materials to conduct grounded research. Furthermore, this paper targets at brands trading in sharing economy and employs online comments from Baidu Reputation as textual materials.

Under the prosumption logic, a brand transforms from a pure product (service) to an intermediary platform that serves as the core resource of the brand. The brands under the prosumption logic in this paper can be understood as platform brands, and the brand itself can be used as a platform to carry other brands. For example, Sina Weibo is a social platform brand jointly created by prosumers, and such platform carries many opinion leaders and We Media. This study targets only at the platform brands like Sina Weibo but not the opinion leaders on these platforms. The above-mentioned opinion leaders and We Media are considered as prosumers who both produce and consume contents on Sina Weibo.

In this study, the business model of platform brand under the prosumption logic is classified as free mode, payment mode and mixed mode in accordance with whether the brand charges prosumers. Under the prosumption logic, the business models of platform brands can be summed up into three categories: the free economy model aiming at exploiting potential product value to achieve brand companies, distributors and consumers a win-win strategy; the payment model aiming at obtaining commissions from every transaction; the mixed mode combining both the features from the above-mentioned two modes.

In the free mode, the brand charges the third-party partners for advertisements and receives commissions to compensate for the cost of some free prosumers, for example: Facebook. In the payment mode, regardless of whether the

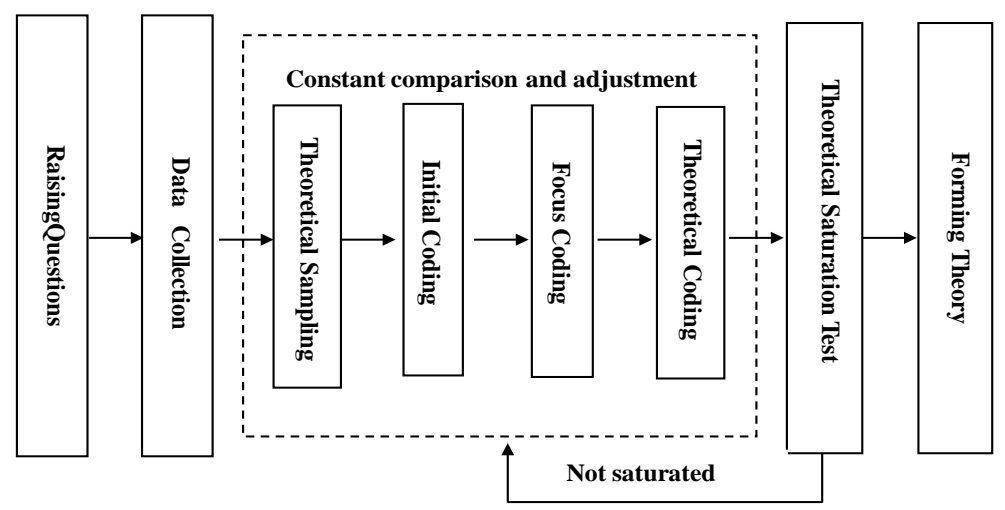

Figure 1. Grounded research process. 
platform uses the $\mathrm{P} 2 \mathrm{P}$ mode or the $\mathrm{B} 2 \mathrm{P}$ model, the platform profits from the commissions for each transaction of the prosumer, and the profit is contingent on the number of transactions on the platform [32], for instance, DiDi. The mixed mode combines both the features of the free mode and the payment model. In this mode, the platform brand receives commissions from some prosumers and charges other brands for advertisements to compensate for the cost of some free prosumers.

As for selecting brands, this paper chooses platform brands that operate with the above three business models. The user generated content (UGC) platform and the sharing economy platform are both typical business models under the prosumption logic. UGC platforms like social media, video sites and fiction sites allow users to demonstrate and provide their original contents to other users via Internet platforms. In addition to UGC platforms in the virtual world, the sharing economy featuring integrated online and offline operations is also a typical business operating model under the prosumption logic, for instance: Airbnb.

During the course of study, this paper makes constant adjustments to the theoretical samplings. Besides the samples from UGC platforms such as social media, video sites and fiction sites, this paper also refers to the sharing economy models and typical cases listed in the Report on the Development of China's Sharing Economy (2017) and makes constant adjustments to the theoretical samplings.

In the end, this paper randomly samples 900 comments of over 80,000 words (excluding suspected comments from paid posters) posted on Baidu Reputation regarding 23 brands, such as Airbnb, Uber, DiDi, jjwxc.com, qidian.com, bilibili.com, zhihu.com, zbj.com, zhongchou.com, xiaozhu.com, wdzj.com, Xianyu, K68, Sina Weibo, rrkd.cn, 51zywl.com, px.zxxk.com, WeChat, meipai.com, miaopai.com, huaban.com, chunyuyisheng.com and yx129.com. The sampled brands cover the aforesaid three business models under the prosumption logic and four types of sharing economy: the sharing of consumption, the sharing of production, the sharing of learning and the sharing of finance. Those brands include both for-profit and nonprofit organizations run by two kinds of different operating modes - P2P and B2P. This paper also uses the Report on the Development of China's Sharing Economy (2017) as reference. The classification of application fields is illustrated in Table 2. This paper believes that UGC websites such as online social media (WeChat, Sina Weibo), video (bilibili.com, meipai.com, miaopai.com), novels (jjwxc.com, qidian.com) and picture sites (huaban.com) are also rightful parts of the sharing economy because they bring in profits for users and brands by allowing users to generate and share their contents. Hence, based on the users' behaviors and purposes, this paper categorizes them as social sharing and entertainment sharing.

This paper adopts 621 comments on 18 brands, roughly $2 / 3$ of the original materials, to conduct the preliminary data analysis, using qualitative coding to form basic dimension structure of brand value. These 18 brands include: Airbnb, 
Table 2. The distribution of brands in areas of sharing economy.

\begin{tabular}{cc}
\hline Application area & Brand \\
\hline Traffic & Uber DiDi \\
Lodging & Airbnb xiaozhu.com \\
P2P network loan & Wdzj.com \\
Crowd funding & Zhongchou.com \\
Life service & Xianyu, rrkd.cn \\
Knowledge and skill & Zhihu.com px.zxxk.com K68 zbj.com \\
Production & 51zywl.com \\
Medical service & Chunyuyisheng.com yx129.com \\
Social sharing* & Wechat Sina Weibo \\
Entertainment sharing* & Video sites (bilibili.com, meipai.com, miaopai.com); fiction (jjwxc.com, \\
\hline
\end{tabular}

Note: * added sharing economies for this study.

Uber, DiDi, jjwxc.com, qidian.com, bilibili.com, zhihu.com, zbj.com, Xianyu, K68, Sina Weibo, 51zywl.com, WeChat, meipai.com, miaopai.com, chunyuyisheng.com and yx129.com. This paper also adopts the remaining 279 comments on 5 brands, about $1 / 3$ of the original materials, to conduct theoretical saturation test. And those five brands include: zhongchou.com, xiaozhu.com, wdzj.com, rrkd.cn and px.zxxk.com.

\section{Research Findings}

\subsection{Initial Coding}

This study applied the data analysis software ATLAS 7 for initial coding. In accordance with the constructivist grounded theory, the author divided the data into different parts by means of verbatim coding and sentence coding in the initial coding stage, defining the actions in the data; the author also underlined the key points in the sentences, clarifying the obscured lines and digging out the subtexts; in addition, the author made comparisons between plenty of data to find out the loopholes and eventually came up with 495 initial codes.

\subsection{Focus Coding}

Focus coding is the second stage of qualitative coding in constructivist grounded theory. Focus coding uses the most critical or the most frequent initial codes to consolidate data. With continuous new ideas, the author made constant adjustments and comparisons in the original data and codes after the first initial coding stage, and eventually came up with the focus codes. This study was inspired by the classical grounded theory and some initial codes were further abstracted into 58 core concepts through repeated analyses and comparisons during focus coding. Afterward, this paper, according to the internal relationship and the logical orders of the core concepts, reclassified the core concepts, hence clarifying 
the internal links and extracting the corresponding categories. In this study, 36 categories are summarized during focus coding, and then these categories are further condensed into a higher-level category, extracting 17 secondary categories, 5 main categories and 1 core category, see Figure 2 for more details.

\subsection{Theoretical Coding}

After the first two stages of initial coding and focusing coding, the author believed that core categories were saturated and the study began stepping into the stage of theoretical construction. At this stage, the author began the theoretical coding stage based on the main categories.

The theoretical coding was performed at a complex level after the focus coding, and the relationships among the main categories formed during focus coding were further embodied. This paper, while taking advice from Strauss and Corbin, also clarified the relationship among the main categories, and arranged such relationships through a drawing to consolidate the generated theories. The typical relational structure of the main categories in this study (storyline) is displayed in Table 3.

This paper thereby constructed the brand value dimension structure model (Figure 3 ) and the brand value dimension path model under the prosumption logic (Figure 4).

The brand value dimension structure model based on the prosumption logic consists of five dimensions: brand experience, brand knowledge, brand relationship strength, brand evangelism and brand citizenship behavior. Brand experience is composed of prosumption experience; brand knowledge consists of brand awareness (association), brand image, perceived quality, perceived value and brand attitude; brand relationship strength is composed of brand attachment, brand trust, brand satisfaction and brand promise; brand citizenship behavior consists of altruistic behavior, support for brand and development behavior; brand evangelism is composed of brand loyalty, brand worship, prosumer worship and the act of attacking competing brand. Under the prosumption logic, the brand value combines cognitive theory, empiricism and relational theory, and is added by two strong productive constructs of brand citizenship and brand evangelism, serving as the expansion of the categories of brand experience, brand knowledge and brand relationship strength.

The main contents of this model include: brand experience is the precondition to both brand knowledge and brand relationship strength, and it also helps create the latter two; brand experience can directly affect brand evangelism and brand citizenship behavior, as well as indirectly influence the aforesaid two through brand knowledge and brand relationship strength. Meanwhile, brand knowledge can directly affect brand evangelism and brand citizenship behavior, and can also indirectly contribute to the creation of brand evangelism and brand citizenship behavior with brand relationship strength as the medium; brand evangelism and brand citizenship behavior, on the other hand, are the results of 


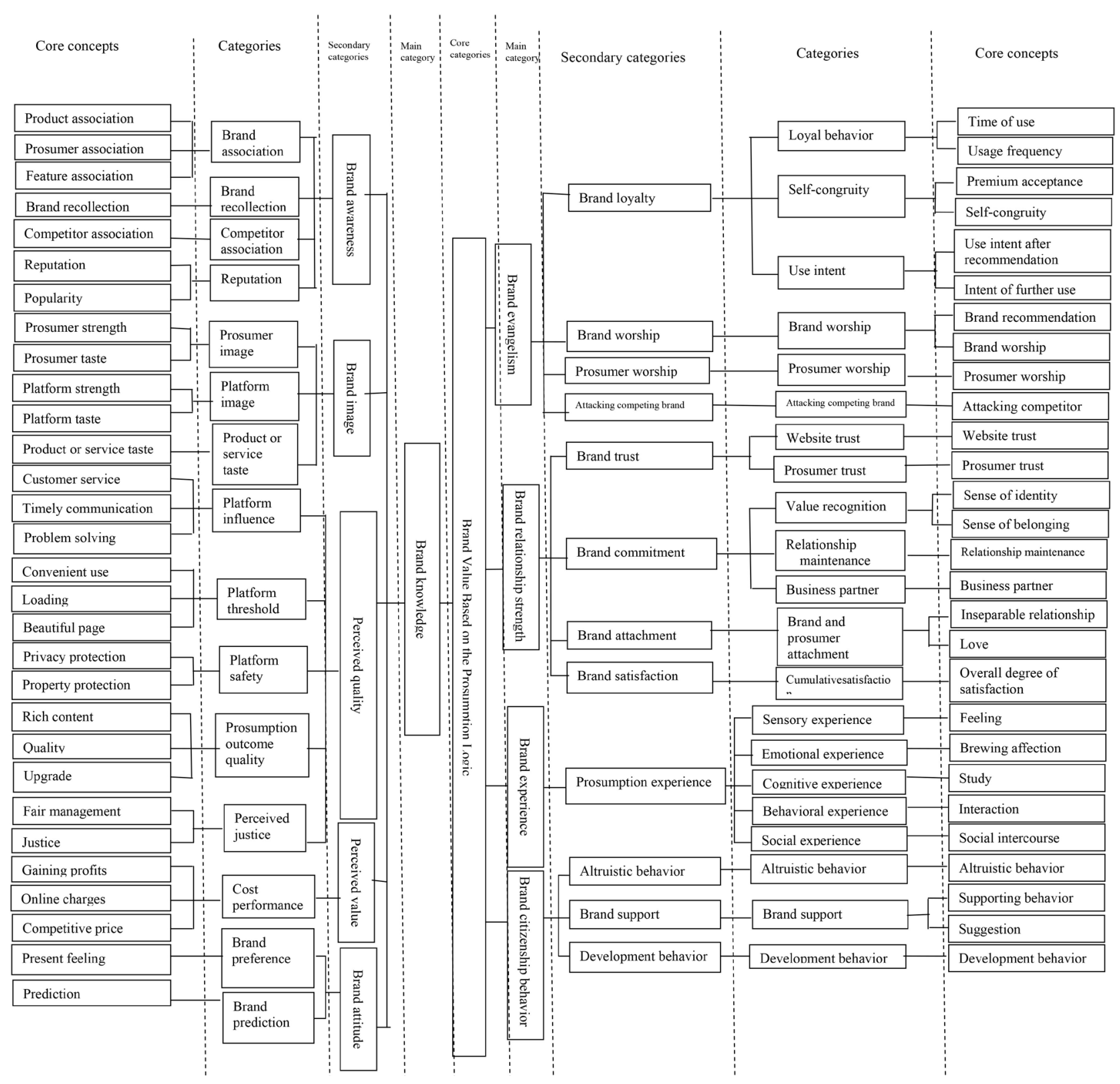

Figure 2. Category relations.

enhanced brand relationship strength; brand evangelism has some influence on brand citizenship behavior; whereas brand evangelism and brand citizenship behavior can stimulate brand experience.

Brand evangelism and brand citizenship behavior are two crucial and powerful productive dimensions. The previous analyses concluded that the key to the profitability of a platform brand is the number of prosumers and prosumption activities. Apart from inspiring people, brand evangelism and brand citizenship behavior also create more prosumption activities; brand evangelism and brand citizenship behavior, in addition, stimulate other prosumers' brand experience, and attract more prosumers. The increase in the number of prosumers will lead to increased prosumption activities. Therefore, the brand evangelism and brand 
Table 3. The typical relational structure of the main categories.

Connotation Respondents' representative statements

Typical relational structure: Brand experience $\rightarrow$ Brand knowledge

Brand experience affects The first time I saw huaban.com I was attracted by its home page. It looks so beautiful that I want to browse brand knowledge. thoroughly. (sensory experience of brand experience) The content in the website won't let you down. You can find all the material you want. (perceived quality of brand knowledge)

Typical relational structure: Brand experience $\rightarrow$ Brand relationship quality

Before the appearance of Airbnb, it is difficult to imagine living in strangers' houses during a journey, and it is much more difficult to imagine welcoming strangers to live in my own house. Now, I have experienced both

Brand experience affects situations and gotten a lot of fun. (behavior experience, emotional experience of brand experience) And because of brand relationship quality.

Airbnb, I have had totally different travel experience. Although this APP is not so perfect, I am glad to see it become better in the future. (brand commitment of brand relationship quality)

Brand knowledge $\rightarrow$ Brand relationship quality

Brand knowledge affects brand relationship quality.
I love it (brand relationship quality), I am a super fan of jjwxc.net and mostly read books on it. On this website, most of the authors will update content on time, and books on the website always match with my interest, whether it be modern romance novels or ancient romance novels. (brand knowledge)

Brand knowledge $\rightarrow$ Brand evangelism

Brand knowledge affects brand evangelism.

A friend recommends this picture website to me. I can find all the pictures I want on this website. (brand loyalty of Brand evangelism) It's so great that I do not have so much trouble to find high-definition pictures. (perceived quality of brand knowledge)

Brand relationship quality $\rightarrow$ Brand evangelism

Brand evangelism affects brand relationship quality.

I like Sina Weibo so much that I always download and uninstall the APP over and over again (brand loyalty of brand evangelism), because I have to force myself to uninstall the APP to inspire myself to study hard every time before an exam, but I am reluctant. (brand attachment of brand relationship quality)

Brand knowledge $\rightarrow$ Brand citizenship behavior

Brand knowledge affects brand citizenship behavior.

I feel hearty that in such a network environment there still exist this kind of real, rational information content. (perceived quality of brand knowledge) I hope this good style can be promoted and I will continue to pay attention, support and study. Thanks! (brand support of brand citizenship behavior)

Brand relationship quality $\rightarrow$ Brand citizenship behavior

Brand citizenship behavior affects brand relationship quality.

In the microblog, people can see the stars' dynamics, they can leave messages, and give the thumbs-up and comment at microblogs of their beloved stars. (altruistic behavior of brand citizenship behavior) Nowadays, the impact of microblog could be seen in all aspects of most people's life, (brand attachment of brand relationship quality) most people share their life dynamics through microblog, and we also learn things by browsing it.

Brand evangelism $\rightarrow$ Brand citizenship behavior

Brand evangelism can drive It is worth recommending (brand evangelism) that we can transfer things we don't need to people who need them. brand citizenship behavior. (brand citizenship behavior)!

Brand evangelism $\rightarrow$ Brand experience

Brand evangelism helps to I opened a shop on zbj.com for three years, (brand loyalty of brand evangelism) and I witnessed myself inspire brand experience. from owning nothing at all to owning a strong team. (knowledge experience of brand experience)

Brand experience $\rightarrow$ Brand evangelism

I learned a lot from this website when I was a college student, (knowledge experience of brand experience) the

Brand experience helps to entire interface design style is very attractive, which indeed caught my attention at the first time. (sensory experience of brand experience) As an art student, I always pursue better things, so I have been using this website from the beginning (brand loyalty of brand evangelism)

Brand experience $\rightarrow$ Brand citizenship behavior 


\section{Continued}

Brand experience helps to inspire brand citizenship behavior.
Most of Sina's news feed are yellow journalism, it is negative and makes me feel desperate. (emotional experience of brand experience) I never browse it but delete directly. (brand citizenship behavior) I really wish Sina website could change this. (brand citizenship behavior)

Brand citizenship behavior $\rightarrow$ Brand experience

Brand citizenship behaviorhelps to inspire brand experience.
The real Witkey platform, the real Witkey home, does not charge any membership fees, we will always support you. (brand support of brand citizenship behavior) The K68 let us have a good development space and more Witkey friends to learn from each other and help each other, (social experience, knowledge experience of brand experience), we are a super big team.

Brand experience $\rightarrow$ Brand knowledge $\rightarrow$ Brand relationship quality

Brand experience indirectly influences brand relationship quality through brand knowledge.
However, one thing happened yesterday disappointed me, (emotional experience of brand experience), which let me find that Didi Taxi is immature and still has its limitation (perceived quality of brand knowledge). It can give no guarantee for the user (the passenger) (brand trust of brand relationship quality).

Brand experience $\rightarrow$ Brand knowledge $\rightarrow$ Brand evangelism

Brand experience indirectly I like photograph, so this website gives me many ideas and its design is original. (knowledge experience of brand influences Brand evangelism experience) This website is quite good, I like it. (brand attitude of brand knowledge ) I always look for materials on through brand knowledge. this website in my work, and it works very well (brand loyalty of brand evangelism).

Brand experience $\rightarrow$ Brand knowledge $\rightarrow$ Brand citizenship behavior

Brand experience indirectly influences brand citizenship behavior through brand knowledge.

Brand experience $\rightarrow$ Brand relationship quality $\rightarrow$ Brand evangelism

Brand experience indirectly influences Brand evangelism through brand relationship quality.

As a college student who often needs to use this kind of material, this website is very helpful to me (knowledge experience of brand experience). In this website you can find not only a variety of works of different designers, but also a lot of modern popular elements, ... (perceived quality of brand knowledge) I hope the website could require designers to explain the connotation of their works when uploading photo materials ... At the same time, I hope the website could give richer contents. (brand support of brand citizenship behavior)

The driver did not come and said nothing!! This will cause me serious trouble!! I am so disappointed. (emotional experience of brand experience) Didi Taxi is the most untrusted APP in all APPs I have used!!!! (brand trust of brand relationship quality) I am so angry (emotional experience of brand experience). Everyone should be cautious! (brand worship of Brand evangelism) Take warning from me, I am really angry!!!! (emotional experience of brand experience)

Brand knowledge $\rightarrow$ Brand evangelism $\rightarrow$ Brand citizenship behavior

Brand knowledge indirectly This website is familiar to most people (brand awareness of brand knowledge), it has a variety of high-definition influences brand citizenship pictures (perceived quality of brand knowledge). It is suitable for those looking for a variety of materials. Also, behavior through Brand evangelism. browsing other people's picture albums could be helpful. (brand worship of brand evangelism) Wish the website could be better. (brand support of brand citizenship behavior)

Brand knowledge $\rightarrow$ Brand relationship quality $\rightarrow$ Brand evangelism

Brand knowledge indirectly influences Brand evangelism through brand relationship quality.
It is such a great, rare website platform (brand attitude of brand knowledge). It is so convenient to safe keep, collect and organize by the help of this website (perceived quality of brand knowledge), so I like huaban.com (brand attachment of brand relationship quality). I would highly recommend. (brand worship of brand evangelism)

Brand experience $\rightarrow$ Brand evangelism $\rightarrow$ Brand citizenship behavior

You can make friends with outstanding people who you will never know in real life, and discuss some specific problems with them and share your own opinions. In this way, you can broaden your horizons and have a better understanding of the world in different aspects! (social experience, knowledge experience of brand

Brand experience indirectly influences brand citizenship behavior through Brand evangelism. experience) ...All in all, I came here especially to made this remark for Quora, and I am a big fan of Quora (brand loyalty of brand evangelism), not because of its so-called elegant style, but its sincere words and the people that attracted me (brand worship of brand evangelism). Just as the page shows 'Your comments are likely to change the world of a person'. (altruistic behavior of brand citizenship behavior) 


\section{Continued}

Brand evangelism $\rightarrow$ Brand experience $\rightarrow$ Brand knowledge

Brand evangelism can inspire brand experience, thereby affecting brand knowledge.
Some time ago, a friend told me that this is the top website producing content in China (brand worship of brand evangelism), I did not feel that before I used in a regular manner (behavioral experience of brand experience). Now, I do think it is the top website in China producing content brand attitude of brand knowledge).

Brand citizenship behavior $\rightarrow$ Brand experience $\rightarrow$ Brand knowledge

Brand citizenship behavior can inspire brand experience, thereby affecting brand knowledge.
Nowadays, many people use WeChat to keep in touch with their friends, and share feelings in Moments (altruistic behavior of brand citizenship behavior). It is convenient to chat by using this APP (social experience of brand experience), it also allows users to transfer money and send red envelopes (behavioral experience of brand experience). However, WeChat started charging a fee for transferring money to personal bank accounts recently, which is inconvenient for us users (perceived value of brand knowledge).

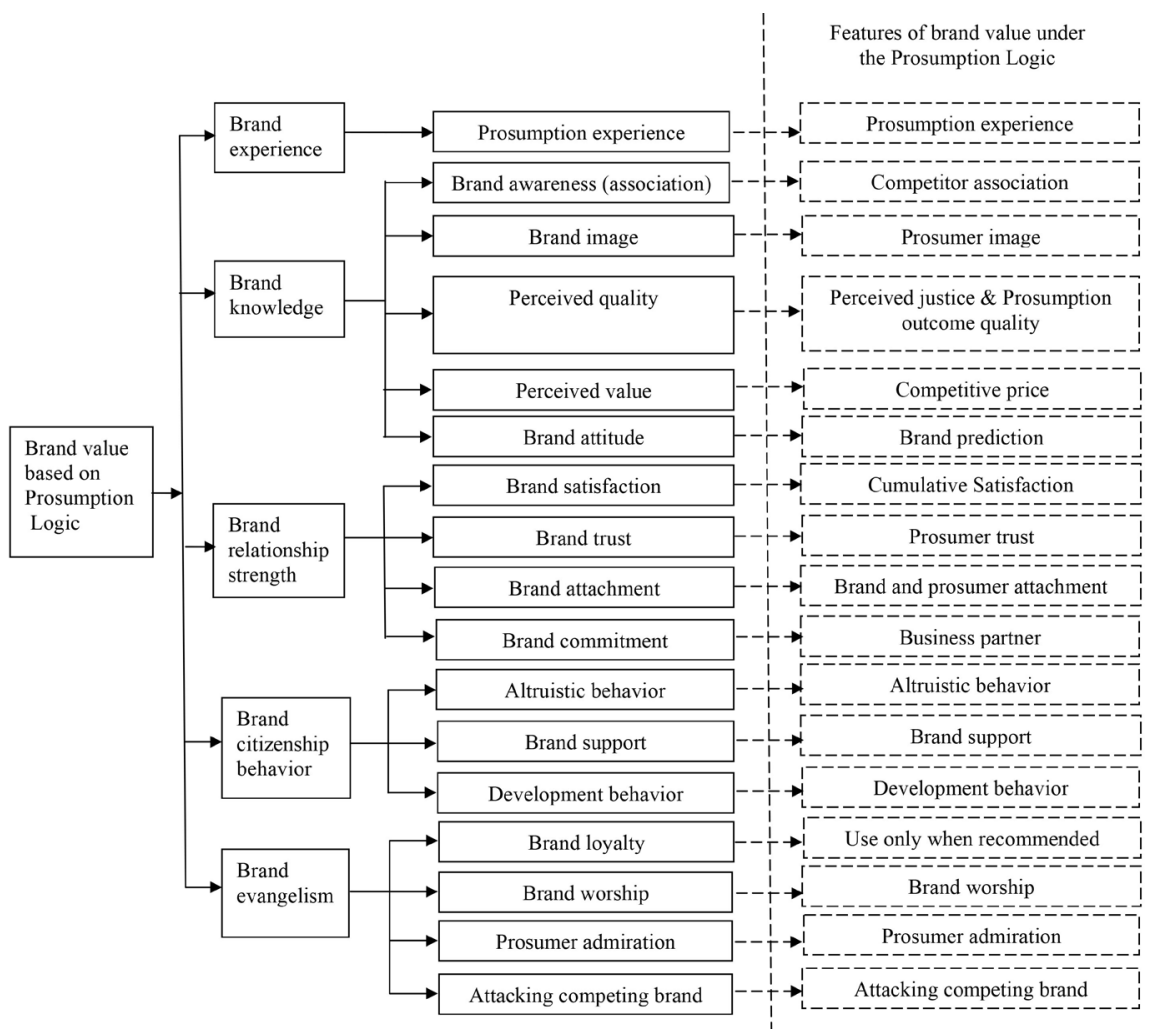

Figure 3. The brand value dimension structure model.

citizenship behavior directly contribute to the establishment of a virtuous circle for the development of the platform brand in accordance with the prosumption logic.

\subsection{Theoretical Saturation Test}

This study adopts 279 comments on 5 brands, including zhongchou.com, xiaozhu.com, wdzj.com, rrkd.cn and px.zxxk.com, over $1 / 3$ of the original materials, to conduct the theoretical saturation test. The results demonstrate that the brand value model based on the prosumption logic has been well developed with no new components in the main category, the subordinate main category 


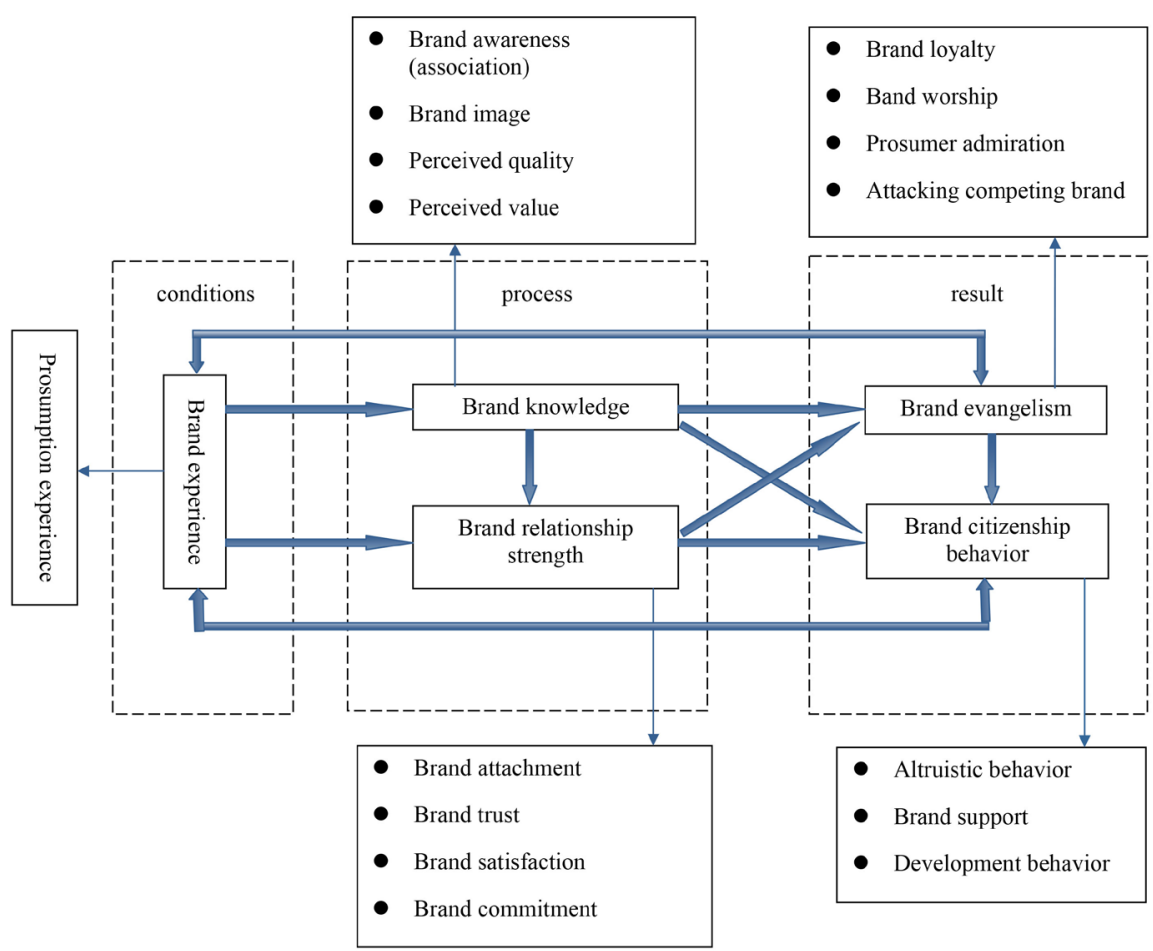

Figure 4. The brand value dimension path concept model.

and the category. Hence, it can be assumed that the brand value dimension structure based on the prosumption logic is theoretically saturated.

\subsection{General Discussion}

In this paper, a three-level code analysis was conducted on the collected materials in accordance with Charmaz constructivist grounded theory to construct both the brand value dimension structure model and the brand value dimension path concept model based on the prosumption logic. As a result, the two models have passed the theoretical saturation test. The brand value dimension structure model is composed of five dimensions: brand experience, brand perception, brand relationship strength, brand evangelism and brand citizenship behavior. In the era of sharing economy platform, the brand value has developed new core concepts and categories out of the existing constructs, leading to the inspirations below:

Full attention should be paid from the web 2.0 platform brands to the dominant role played by the prosumers related to the brand benefits and the relevant value co-creation mechanism. In the era of the sharing economy, the major evaluation subject of the brand's value is no longer the consumers, but the prosumers and other stakeholders who, while enjoying the services provided by the brand, also produce product (service). Because the brand is created by prosumers' activity, the prosumers assume themselves as the representative of the brand. Dimensions like brand experience, brand awareness, brand image, perceived quality, brand satisfaction, brand trust, brand attitudes, brand attachment 
and brand commitment have all expanded the core concepts or categories that are applied to highlight the dominant role of the prosumer, leading to the creation of prosumption experience, prosumer association, prosumer image, prosumption outcome quality, prosumer satisfaction, prosumer trust, prosumer future expectation, prosumer attachment and business partners.

Web2.0 platform brands should fully recognize the competitors and use them for brand value enhancement. Brand association has developed a new dimension named "competitor association", and perceived value has also expanded a new dimension named "competitive cost-efficiency". In the previous brand association measurement, testees were often asked to think of a certain product to see if they can recall a particular brand. With the sharing economy, the prosumers now can not only recall a specific brand, but also point out the relevant competitors. When calculating the cost-efficiency of a brand, the prosumers will also consider the extra opportunity cost due to the existence of competitors. Furthermore, most of the sharing economy market segments are free markets at the very beginning, and then evolve into an oligopoly market, and ultimately become a market where winners take all due to fierce competitions. Unfortunately, the reasons behind this phenomenon are quite complicated. Nevertheless, this paper argues that the prosumer's "competitor association" and "competition cost-efficiency" have played a critical part. It is also worth noting that whether "competitor association" and "competitive cost-efficiency" yield a positive or negative impact on the brand itself is hardly a foregone conclusion. Brand that is good at "taking advantage of the situation" is able to capitalize on the competition to enhance the prosumer's positive perception, thus promoting the relationship between the prosumer and the brand.

Web2.0 platform brands are able to have its brand value dramatically increased by inspiring brand evangelism and brand citizenship behavior. As two powerful productive dimensions, brand evangelism and brand citizenship behavior could stimulate other people's brand experience while inspiring prosumption activities. By means of attracting other prosumers to create prosumption activity, the above two dimensions promote a virtuous circle that is significant to the profitability of the brand under the prosumption logic. Brand evangelism and brand citizenship behavior drive the formation of a closed loop which guarantees the continuous operation of production and consumption as well as the successful circulation of prosumption. With the sharing economy, the brand value is co-created by the prosumer, the representative of the brand stakeholders, and platform brand. Therefore, the circle of prosumption equals the circle of value co-creation and the brand value is thereby born.

Building on the brand value dimension structure, this paper further explores the action mechanism among different brand value dimensions. After analyzing the interdependent relationship among different brand value dimensions, this paper proposes the following management suggestions: using brand experience as a lever to increase brand value; enhancing brand knowledge to improve brand relationship strength; consolidating brand evangelism to inspire brand citizen- 
ship behavior. Those suggestions are made with a view to serve as a reference and to add in the enterprise's efforts to efficiently manage its brand via the utilization of marketing resources.

\subsection{Limitations and Future Research}

This paper raised a new construct of brand value based on the prosumption logic, and explored the relevant five dimensions. Every construct and its categories involve the existing concepts, yet all of them were given a new touch against the backdrop of the sharing economy. Among those newly established core concepts and categories are prosumption experience, competitor association, prosumer image, prosumption outcome quality, perceived justice, competitive cost-efficiency, cumulative satisfaction, prosumer trust, brand future prediction, brand and prosumer attachment, business partner, use intention after being recommended, brand evangelism, prosumer worship, attacking competing brand, altruistic behavior, brand support, and development behavior.

prosumption theory is not a comprehensive theory yet, and the previous documents only offer little help to the existing brand value study in the era of sharing economy platform. This paper builds on the previous brand value theories and introduces the one based on the prosumption logic. In this sense, it can be assumed that this paper has made some theoretical contributions to the studies on brand value in the era of sharing economy platform through theoretical innovation. In addition, by analyzing the grounded theory, this paper uncovers two powerful productive dimensions known as brand evangelism and brand citizenship behavior, and further expands the denotation and connotation of brand experience, brand knowledge, brand relationship strength, as well as highlights the new features developed by previous concepts.

Unfortunately, although the rise of prosumption capitalism is happening on the global scale, this paper only focuses on the corresponding situation in China. Future studies may be conducted outside China so that comparisons can be drawn between different brand value models under the prosumption logic in the intercultural setting. Moreover, the brand value theoretical model established in this study requires empirical studies in order to further explore the internal mechanism and the system of governance for the value co-creation of platform brand under the framework of sharing economy.

\section{Conflicts of Interest}

The authors declare no conflicts of interest regarding the publication of this paper.

\section{References}

[1] Ritzer, G. and Jurgenson, N. (2010) Production, Consumption, prosumption: The Nature of Capitalism in the Age of the Digital 'Prosumer'. Journal of consumer culture, 10, 13-36. https://doi.org/10.1177/1469540509354673

[2] Toffler, A. (2006) Revolutionary Wealth. Zhongxing Press, Beijing (In Chinese). 
https://doi.org/10.1111/j.1540-5842.2006.00818.x

[3] Quain, B. (2006) Pro-Sumer Power!: How to Create Wealth by Buying Smarter, Not Cheaper! INTI Pub \& Resource Books Incorporated.

[4] Ritzer, G., Dean, P. and Jurgenson, N. (2012) The Coming of Age of the Prosumer. American Behavioral Scientist, 56, 379-398. https://doi.org/10.1177/0002764211429368

[5] Shah, S., Shen, L., Ali, M., Doronin, D. and Hussain, S. (2019) prosumption: Bibliometric Analysis Using HistCite and VOSviewer. Kybernetes. (In Press)

[6] Ritzer, G. (2014) The "Sharing” Economy, Uber, and the Triumph of Neo-Liberalism. https://georgeritzer.wordpress.com/2014/11/05/the-sharing-economy-uber-and-the -triumph-of-neo-liberalism/

[7] Rifkin, J. (2014) The Zero Marginal Cost Society. Zhongxing Press, Beijing (In Chinese).

[8] Hu, H., Huang, T., Cheng, Y. andLu, H. (2019) The Evolution of Sustainable Business Model Innovation: Evidence from a Sharing Economy Platform in China. Sustainability, 11, 4207. https://doi.org/10.3390/su11154207

[9] Na, Y.K., Kang, S. and Jeong, H.Y. (2019) Sub-Network Structure and Information Diffusion Behaviors in a Sustainable Fashion Sharing Economy Platform. Sustainability, 11, 3249. https://doi.org/10.3390/su11123249

[10] Christodoulides, G. and Chernatony, L.D. (2010) Consumer-Based Brand Equity Conceptualization and Measurement. International Journal of Market Research, 52, 43-66. https://doi.org/10.2501/S1470785310201053

[11] Prahalad, C.K. and Ramaswamy, V. (2004) Co-Creation Experiences: The Next Practice in Value Creation. Journal of Interactive Marketing, 18, 5-14.

https://doi.org/10.1002/dir.20015

[12] Vargo, S.L. and Lusch, R.F. (2004) Evolving to a New Dominant Logic for Marketing. Journal of marketing, 68, 1-17. https://doi.org/10.1509/jmkg.68.1.1.24036

[13] Mangold, W.G. and Faulds, D.J. (2009) Social Media: The New Hybrid Element of the Promotion Mix. Business Horizons, 52, 357-365. https://doi.org/10.1016/j.bushor.2009.03.002

[14] Grönroos, C. (1997) Keynote Paper From Marketing Mix to Relationship Marketing-Towards a Paradigm Shift in Marketing, Management Decision, 35, 322-339. https://doi.org/10.1108/00251749710169729

[15] Payne, A., Storbacka, K., Frow, P. and Knox, S. (2009) Co-Creating Brands: Diagnosing and Designing the Relationship Experience. Journal of Business Research, 62, 379-389. https://doi.org/10.1016/j.jbusres.2008.05.013

[16] Bagozzi, R.P. (1975) Marketing as Exchange. The Journal of Marketing, 39, 32-39. https://www.jstor.org/stable/1250593 https://doi.org/10.1177/002224297503900405

[17] Porter, M.E. (2001) The Value Chain and Competitive Advantage. Understanding Business: Processes, 50-66.

[18] Xie, C., Bagozzi, R.P. and Troye, S.V. (2008) Trying to Prosume: Toward a Theory of Consumers as Co-creators of Value. Journal of the Academy of Marketing Science, 36, 109-122. https://doi.org/10.1007/s11747-007-0060-2

[19] Marx, K. and Angels, F. (1998) Complete Works of Marx and Engels. People's Publishing House, Beijing.

[20] Pietrykowski, B. (2007) Exploring New Directions for Research in the Radical Political Economy of Consumption. Review of Radical Political Economics, 39, 257-283. 
https://doi.org/10.1177/0486613407302487

[21] Cardador, M.T. and Pratt, M.G. (2006) Identification Management and its Bases: Bridging Management and Marketing Perspectives through a Focus on Affiliation Dimensions. Journal of the Academy of Marketing Science, 34, 174-184. https://doi.org/10.1177/0092070305284984

[22] Toffler, A. (1981) The Third Wave. Bantam Books, New York.

[23] Kotler, P. (1986) The Prosumer Movement: A New Challenge for Marketers. Advances in Consumer Research, 13, 510-513.

[24] Tapscott, D. and Williams, A.D. (2007) Wikinomics: How Mass Collaboration Changes Everything. Portfolio.

[25] Seran, S. and Izvercian, M. (2014) Prosumer Engagement in Innovation Strategies: The Prosumer Creativity and Focus Model. Management Decision, 52, 1968-1980. https://doi.org/10.1108/MD-06-2013-0347

[26] Shen, L. and Wei, XY. (2016) prosumption Behaviors in Sharing Economy: Literature Review and Research Direction. Creative Economy and Management, 1, 18-25 (In Chinese).

[27] Shen, L. and Zheng, Z.Y. (2014) A Review of Context of Online Consumer Behaviorand the Construction of Double-Track Online Consumer Decision-Making Model. Foreign Economics and Management, 8, 53-61 (In Chinese). http://www.cnki.com.cn/Article/CJFDTOTAL-WGJG201408006.htm

[28] Shen, L. and Zheng, Z.Y. (2019) Web 2.0 prosumption: Essence and the Value Logic. Forecasting, 3, 91-96 (In Chinese). http://www.cnki.com.cn/Article/CJFDTOTAL-YUCE201903014.htm

[29] Shen, L. and Wei, X.Y. (2016) The Production and Consumption Activities in the Sharing Economy: A Review and Direction. Journal of Creative Economy and Management, 1, 18-25. (In Chinese)

[30] Anker, T., Sparks, L., Moutinho, L. and Grönroos, C. (2015) Consumer Dominant Value Creation: A Theoretical Response to the Recent Call for a Consumer Dominant Logic for Marketing. European Journal of Marketing, 49, 532-560. https://doi.org/10.1108/EJM-09-2013-0518

[31] Botsman, R. and Rogers R. (2010) What's Mine Is Yours: The Rise of Collaborative Consumption. Harper Business, New York.

[32] Botsman, R. The Sharing Economy Lacks a Shared Definition. https://georgeritzer.wordpress.com/2014/11/05/the-sharing-economy-uber-and-the -triumph-of-neo-liberalism/

[33] Schor, J.B. and Fitzmaurice, C.J. (2015) Collaborating and Connecting: The Emergence of the Sharing Economy. Handbook of Research on Sustainable Consumption. Edward Elgar, Cheltenham, UK.

[34] Yoo, B. and Donthu, N. (2001) Developing and Validating a Multidimensional Consumer-Based Brand Equity Scale. Journal of Business Research, 52, 1-14. https://doi.org/10.1016/S0148-2963(99)00098-3

[35] Brakus, J.J., Schmitt, B.H. and Zarantonello, L. (2009) Brand Experience: What Is It? How Is It Measured? Does It Affect Loyalty? Journal of Marketing, 73, 52-68.

[36] Farquhar, P. H. (1989) Managing Brand Equity. Marketing Research, 1, 24-33.

[37] Suddaby, R. (2006) From the Editors: What Grounded Theory Is Not. Academy of Management Journal, 49, 633-642. https://doi.org/10.5465/amj.2006.22083020

[38] Charmaz, K. (2009) Constructing Grounded Theory: A Practical Guide through 
Qualitative Analysis. Chongqing University Press, Chongqing. (In Chinese)

[39] Lassar, W., Mittal, B. and Sharma, A. (1995) Measuring Customer-Based Brand Equity. Journal of Consumer Marketing, 12, 11-19.

https://doi.org/10.1108/07363769510095270 